\title{
Global Trade in Stolen Culture and Nature as Neocolonial Hegemony
}

Citation for published version (APA):

Mackenzie, S., Hubschle, A., \& Yates, D. (2020). Global Trade in Stolen Culture and Nature as Neocolonial Hegemony. In J. Blaustein, K. Fitz Gibbon, N. Pino, \& R. White (Eds.), Emerald Handbook of Crime, Justice and Sustainable Development (pp. 419-436). Emerald Publishing.

https://doi.org/10.1108/978-1-78769-355-520201023

Document status and date:

Published: 01/01/2020

DOI:

10.1108/978-1-78769-355-520201023

Document Version:

Publisher's PDF, also known as Version of record

Document license:

Taverne

Please check the document version of this publication:

- A submitted manuscript is the version of the article upon submission and before peer-review. There can be important differences between the submitted version and the official published version of record.

People interested in the research are advised to contact the author for the final version of the publication, or visit the DOI to the publisher's website.

- The final author version and the galley proof are versions of the publication after peer review.

- The final published version features the final layout of the paper including the volume, issue and page numbers.

Link to publication

\footnotetext{
General rights rights.

- You may freely distribute the URL identifying the publication in the public portal. please follow below link for the End User Agreement:

www.umlib.nl/taverne-license

Take down policy

If you believe that this document breaches copyright please contact us at:

repository@maastrichtuniversity.nl

providing details and we will investigate your claim.
}

Copyright and moral rights for the publications made accessible in the public portal are retained by the authors and/or other copyright owners and it is a condition of accessing publications that users recognise and abide by the legal requirements associated with these

- Users may download and print one copy of any publication from the public portal for the purpose of private study or research.

- You may not further distribute the material or use it for any profit-making activity or commercial gain

If the publication is distributed under the terms of Article $25 \mathrm{fa}$ of the Dutch Copyright Act, indicated by the "Taverne" license above, 


\title{
Global Trade in Stolen Culture and Nature as Neocolonial Hegemony
}

\author{
Simon Mackenzie, Annette Hübschle and Donna Yates
}

\begin{abstract}
In this chapter, we first argue for a green criminological perspective on culture as well as nature, as those concepts are framed in the United Nations Sustainable Development Goals. Second, from within this green criminological perspective we discern a neocolonial hegemony in the resource extraction from developing countries that is represented by international trafficking markets in looted cultural heritage and poached wildlife. In other words, developed nations benefit from these trades while developing nations suffer, and governance regimes attempting to control these global criminal trades prioritise the rational interests and cultural norms of the more powerful market nations over the local interests and cultural histories of communities at the source of the chain of supply. Finally, our third argument is that the emerging intellectual framework of sustainable development, as represented in the UN's goals, may provide a perspective on the issue of trafficking culture and nature that can push back against the neocolonial hegemony of international criminal markets such as these.
\end{abstract}

Keywords: Cultural heritage; wildlife trafficking; transnational crime; neocolonialism; sustainable development and political economy; natural heritage; green criminology; environmental justice; local communities

\section{Introduction}

The collection of 17 Sustainable Development Goals (SDGs) and 169 indicators is the latest United Nations instalment in a long row of measures aimed at facilitating pathways to sustainable development for all of the world's citizens. The United Nations General Assembly launched the SDGs in 2015 as part of the 2030 Agenda for Sustainable Development. The SDGs stretch from potable water and sanitation for all to ending global poverty, but the focus of our chapter is on the

\footnotetext{
The Emerald Handbook of Crime, Justice and Sustainable Development, 419-436

Copyright $(1) 2021$ Simon Mackenzie, Annette Hübschle and Donna Yates

Published under exclusive licence

doi:10.1108/978-1-78769-355-520201023
} 
target in SDG 11.4, which aims to 'strengthen efforts to protect and safeguard the world's cultural and natural heritage'. For critical researchers who study trafficking crimes in antiquities and wildlife, this goal is good to see. At the same time, it skates on some thin ice beneath which the waters run deep. As we shall develop at more length in this chapter, the notion of 'heritage' is a contested concept, deeply anchored in colonial discourses, while the associated concepts of 'preservation', 'conservation' and 'protection' are linked to global policies that have been disparaged by critical scholars as paternalistic and one-sided (Garland, 2008; Ramutsindela, 2006; White, 2014).

For antiquities trafficking, the international policy narrative has in fact been framed in terms of strengthening protection efforts since at least 1970, when the main international convention that continues to govern this type of crime, the UNESCO Convention on the Means of Prohibiting and Preventing the Illicit Import, Export and Transfer of Ownership of Cultural Property, noted that 'it is incumbent upon every State to protect the cultural property existing within its territory against the dangers of theft, clandestine excavation, and illicit export' and that States should

...undertake to oppose such practices with the means at their disposal, and particularly by removing their causes, putting a stop to current practices, and by helping to make the necessary reparations. (UNESCO 1970)

Meanwhile, wildlife trafficking has been subject to a system of trade regulation since the Convention on International Trade in Endangered Species of Fauna and Flora (CITES) came into force in 1975. While the UNESCO Convention deals with antiquities trafficking overtly, CITES provides a regulatory framework for international trade in endangered wildlife species. The principal aim of the multilateral environmental agreement is to ensure that international trade in specimens of wild animals and plants does not threaten the survival of the species in the wild, and it accords degrees of protection to nearly 36,000 species of animals and plants. The question arises then: what if anything does the latest framing of these issues as SDGs add to the international policy movement to combat these two contemporary forms of transnational crime?

The ethics of dealing in and collecting antiquities is a debate that has been significantly influenced for too long by the powerful voices of those with vested interests in the trade. The framework by which we come to understand antiquities trafficking, which we will hereafter refer to as 'trafficking culture' (see Mackenzie, Brodie, Yates, \& Tsirogiannis, 2019), is in significant part a hegemonic liberal market discourse that marginalises and misrepresents the interests of local communities living with or near the heritage in question - that is to say, in the market discourse, 'at source' (of the chain of supply). The same applies to the poaching and illegal harvesting of animals and plants, which are often intricately linked to the livelihood strategies and food security of local communities, but in respect of which the international regulatory framework assumes a norm of free trade and international movement. Can the conceptual framework of sustainable 
development provide a counterbalance to these market-oriented discourses? Can it help to provide clarity on the resolution of previously intractable debates between the seemingly incomparable poles of market trade and environmental protection? In this chapter, we will consider the extent to which that might be the case. First, we will make an argument for considering trafficking culture, as well as trafficking nature, from the perspective of green criminology. Next, we will use that green criminological perspective to consider trafficking in culture and nature as examples of a trade-based neocolonial hegemony. In our version of this argument, both the global trafficking in culture/nature and the international regulatory responses to these transnational crimes display such hegemonic qualities. Third, and finally, we will look to the SDGs and the vision of sustainable development for intellectual tools to resist the neocolonial hegemony of these markets.

We argue in this chapter that the global systems represented by antiquities looting, trafficking and market collection, and the illegal hunting of wildlife, trafficking and trade, are models for an unsustainable type of development - both for the source countries from which the items are extracted in a destructive manner for short-term economic gain and for the wealthier market countries where the social and moral fabric is warped by the normalisation of the cultural celebration of illicitly obtained goods. Thinking about illicit trade only in terms of markets - in other words conducting arguments in a crucible constructed only from an economic paradigm - pushes important sustainable development issues like justice, history and human rights to the margins of consideration. An SDG perspective on these debates may offer a fresh and productive take on what have become entrenched and normalised pernicious features of the global economic system.

\section{Culture, Nature and Green Criminology}

Thanks to the emerging green criminology, wildlife trafficking is seen as an environmental crime, as well as a form of organised crime. The ecological destruction inherent in wildlife crime is clearly conceived (White, 2010, 2011). At least it is considerably more clearly conceived than the detrimental effects of antiquities looting and trafficking. Whether the latter is an 'environmental' crime or a 'green' issue is not a question that has so far elicited much, if any, discussion. There are good reasons to think that holding antiquities crimes alongside green criminology may be a productive move, though. Searching unlawfully for antiquities can cause serious environmental destruction: witness the many photos and satellite pictures of landscapes pock-marked by looters holes that pervade the literature (Brodie, Doole, \& Renfrew, 2001). Dense vegetation around jungle sites are areas that are liable to be cut back to allow access to temples and shrines, and where heavy machinery is used to facilitate the extraction the damage may be considerable (Yates, 2014b).

Yet, for us, the most clarity in associating antiquities looting with green criminology is achieved when cultural heritage sites are considered to be part of the environment rather than just existing as repositories of man-made objects in or 
on the environment. In many places, temples and other structures have become such an integral part of the landscape it is not really viable to think of them as 'stuff' on that landscape - rather these pieces of evidence of bygone civilisations are the marks left on the landscape by our forebears and in that respect are as much a part of the living environment as it now presents to us as are the forests or deserts in which they sit. Likewise, deposits of antiquities buried underground may surely at some point rightly come to be considered a 'naturally occurring' part of the environment, no different from other such deposits like fossil fuels or gemstones, especially since their extraction involves environmentally destructive practices precisely comparable to other types of resource extraction. We may not be talking about fracking or massive deforestation here but look at the before/ after satellite feed of the Apamea site in Syria and make your own mind up about whether looting is an environmental crime (see Fig. 20.1). ${ }^{1}$

With the SDGs now on the global agenda, the issue of whether certain criminal trades are environmental crimes is not an intellectual indulgence but rather it brings with it a raft of practical consequences. It is an interesting aspect of the SDGs that they hint at this link between crimes against culture and crimes against nature by including them both in Goal 11 while having an entirely separate goal for the protection of ecosystems and biodiversity in Goal 15. UNODC engages with Goals 11 and 15 by linking from both to a webpage outlining its strategy on Wildlife and Forest Crime in the Southeast Asia and Pacific region. Clearly the sense is that while from the perspective of development thinkers the two Goals are about separate issues, when one takes a criminological view of matters it seems that there is an emerging recognition here of culture/nature/environment as being a cluster of ideas that cohere and 'fit' together as a group of interests to be protected. A culture-nature nexus, if you will. This is a far cry from earlier notions of the culture-nature divide, which pervades much of scholarly thinking and theorising.

Green criminology brings a set of conceptual tools and orientations that encourages researchers to identify and uncover hidden exercises of power and in that way orients us towards stripping corporate, state and market ideology away from the framing of global environmental challenges (Lynch \& Stretesky, 2014; Ruggiero \& South, 2010; White \& Heckenberg, 2014). The sustainable development issues facing culture and nature can in this vein be seen in the context of a legacy of colonial 'conquest and collection' type of thinking which once we have identified it can then be critiqued.

\section{Trafficking Culture and Nature as Neocolonial Hegemony}

Both of these policy domains, antiquities trafficking and wildlife trafficking, are in some measure characterised by competing discourses that seek to establish themselves as the appropriate way to interpret the activities in question: as normal forms of international trade, as local and national issues of the discovery and use of the natural and cultural environment or as crime. A frame of reference is

\footnotetext{
${ }^{1}$ https://traffickingculture.org/data/looting-at-apamea-recorded-via-google-earth/.
} 

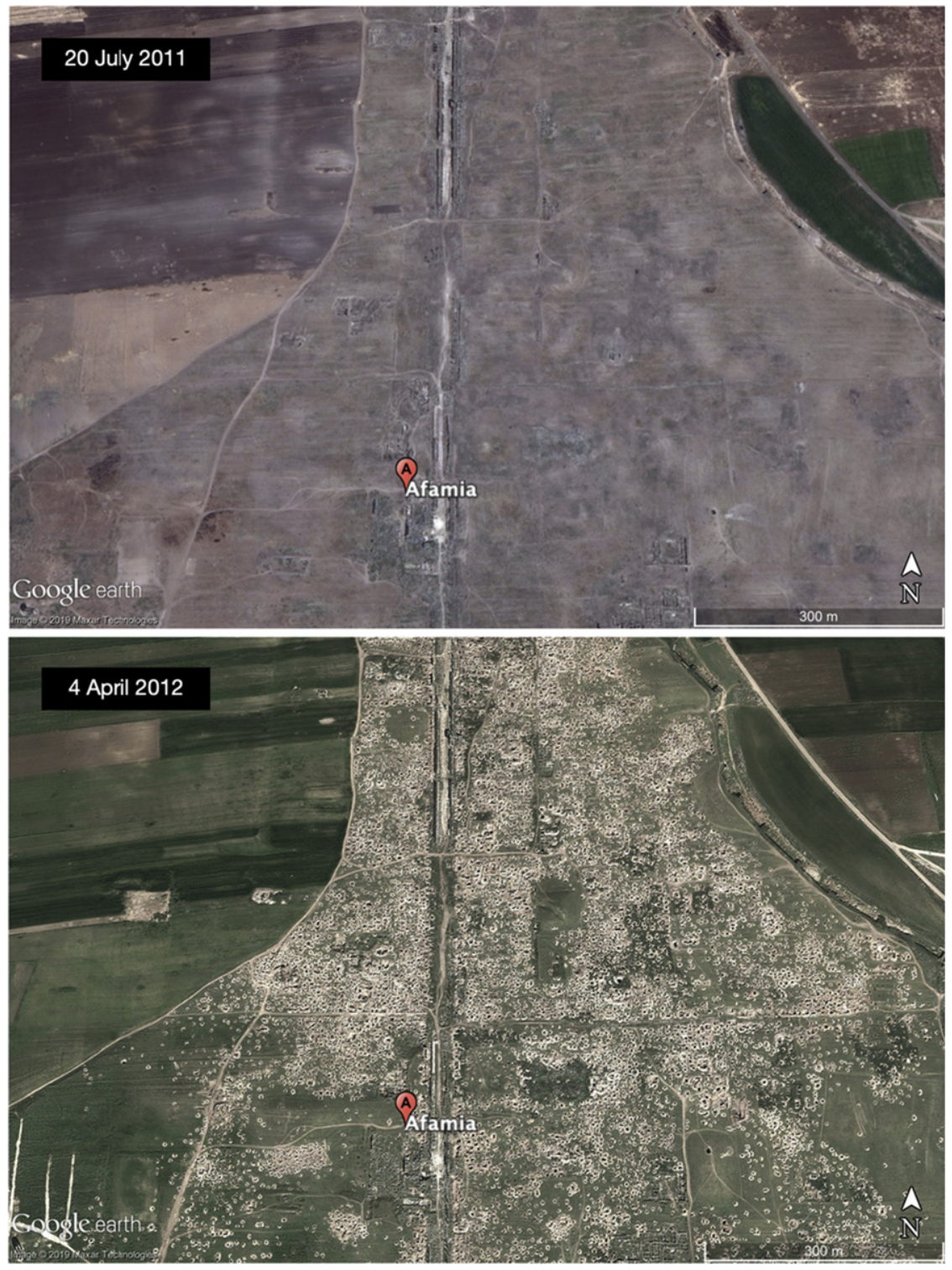

Fig. 20.1. Impact of Antiquities Extraction at the Apamea Site in Syria. Map data: Google, Maxar Technologies.

needed that allows the debate to step out of the dichotomy of a 'collecting versus conservation' viewpoint: this alternative frame needs to respect ideas including human rights, global justice and cultural or communal ownership and interest in heritage (Mackenzie \& Yates, 2017). 


\section{Trafficking Culture}

The various forms of harm involved in trafficking culture are diminished in the ethical debate about illicit antiquities by well-worn appeals to justifications and excuses that depend on one accepting that certain considerations are more salient than others: for example, that object preservation in homes and galleries, and publication in museums and exhibitions, is more important than the archaeological record of excavation which is lost through looting (Cuno, 2008; Mackenzie, 2005). On the most fundamental level of social meaning, therefore, the 'problem' of looting and trafficking antiquities is a disputed object - the scare quotes used because many collectors and dealers simply do not consider it a problem at all (Mackenzie, 2013). Various attempts have been made over recent decades to engage with this issue of a lack of an overall accepted reference framework within which to place the unlawful extraction of antiquities and their clandestine movement across borders as part of the global art market system.

On behalf of the international capitalists of the art market, one of the most famous contributions to the collecting perspective has been made by John Henry Merryman, a legal academic and self-styled 'cultural internationalist' (Merryman, 2005), whose central concern was with what he saw as the 'retentionist' policies of source countries for antiquities (Merryman, 1988). He thought such retentionism was unfair because it denied the aficionados of the Global North the opportunity to indulge their passion for appreciating ancient art through collection. In his view, cultural heritage was the property of all humankind - a position which has been written through ongoing contemporary debates about the ethics and responsibilities of 'encyclopedic museums' harbouring collections sourced from around the world and inevitably including many items with dubious origins. For contemporary acquisitions those dubious origins tend to involve a fake or absent trail of provenance, and for older acquisitions the case is more likely to fall into the category of the moral standards of yesteryear, where objects were collected in a time when the whole issue of taking things from former colonies was viewed very differently.

\section{Trafficking Nature}

Much of the global illegal trade in wildlife originates in biodiverse-rich nations in the Global South. A common myth is that almost all wildlife is destined for Asian markets (Margulies, Wong, \& Duffy, 2019b). However, researchers have consistently shown that illegal wildlife markets are spread across the globe, including many sites located in Europe and Northern America (Floyd, 1998; Hübschle, 2016; Margulies et al. 2019a; Reuter \& O'Regan, 2017; Stiles, 2015). The illegal wildlife trade has been identified as the fourth most lucrative organised crime market in the world by several conservation and crime fighting organisations. This contention relies on the guestimate of researchers linked to Global Financial Integrity (Harken, 2011). While the veracity of the statistics has been questioned (Fioramonti, 2014), there is no doubt that the illegal wildlife trade is affecting biodiversity and species extinction. Another common mistake is the 
assumption that all trade in wildlife is illegal when in fact, a great proportion of trade in wildlife is considered legal and sustainable (Broad, Mulliken, \& Roe, 2003). While organised crime networks are involved in some high-value trades including charismatic megafauna (Rademeyer, 2016, pp. 1-64), caviar (Zabyelina, 2014) and abalone (de Greef \& Raemakers, 2014; Lambrechts \& Goga, 2016), wildlife industry professionals and individual collectors are involved in the trade of less charismatic wildlife (Hübschle, 2017a; Wyatt, 2009). Many illegal wildlife trades have distinct value and supply chains with their own set of market mechanisms, drivers and dynamics (UNODC, 2016). There are a few examples where convergence between illegal wildlife trade and other organised crime activities has been observed (Hübschle \& de Greef, 2016; Shelley, 2018). However, scholars and law enforcement officials have rejected claims that the illegal wildlife trade is linked to the funding of international terrorism (Duffy et al. 2019; Maguire \& Haenlein, 2015; Titeca \& Edmond, 2019). There is growing evidence of an interface between illegal wildlife markets and a bouquet of legal economies and markets including, for example, real estate, construction and banking (Hübschle, 2016; Hübschle \& Shearing, 2020).

Criminologists have set the tone in the literature on wildlife trafficking by describing the crime, profiling wildlife offenders and providing instrumental explanations why wildlife crime is perpetrated, such as motivations to poach, and structural or geographic drivers. Another stream of literature describes the illegal wildlife trade as a 'global supply chain' or 'global production chain' that is demand-driven and dominated by organised crime networks (van Uhm, 2016; Wong, 2015; Wyatt, 2013). Many scholars describe the supply side of wildlife markets, focussing almost exclusively on the first segment or stage of the supply chain with little consideration of what happens further down the chain. Scholars thus portray 'poachers' as the principal suppliers of wildlife contraband, ignoring the role of the state, the wildlife industry, NGOs and criminal networks in the overall market structure. The supply chain is split into source, transit and consumer markets. As comparatively little is known about the transit zones and consumer markets, remedial responses have largely focused on disrupting illegal hunters, fishers, loggers and harvesters in source markets. These low-level suppliers have been on the receiving end of disproportionate often militarised responses, while organisers, intermediaries, traffickers and traders remain unscathed and largely untouchable.

Wildlife conservation often clashes with local interests. A CITES listing on one of the three Appendices or regulatory change at the domestic level can render someone's livelihood strategy an illegal activity. This person may have been a fisher, hunter or woodcutter in the past and from one day to the next is considered to be breaking the law and branded a poacher, illegal fisher or illegal logger.

\section{Heritage, Modernisation and Development}

Another benefit of drawing remedial responses to crimes against natural and cultural heritage sites together for analysis is the comparably problematic use of 
the 'heritage' concept in both discourses. In the arena of nature conservation, the concept of 'natural heritage' invokes problematic colonial and somewhat archaic tropes which tally with notions of game parks as African configurations of the Garden of Eden or Teddy Roosevelt's labelling of Yosemite National Park as 'a great solemn cathedral'. While appreciation of nature is not wrong per se, the notion of heritage is muddied in controversies. In the African version of conservation, local and indigenous people have been excluded from conservation since the first antipoaching measures were introduced in colonial times (Carruthers, 1995, 2017; Garland, 2008). So-called 'fortress conservation' reifies an approach that seeks to preserve wildlife and their habitat through the forceful exclusion of local people from conservation areas. Local people are portrayed as the enemies of wildlife and of protected areas, which are preserved or restored through Western science, expertise and donations (Brockington, 2002; Igoe, 2002). In recent years, the paradigm has included conservationist notions of 'biodiversity', 'payment for ecosystems services', 'transfrontier conservation' and community-based natural resource management initiatives which promote the view that local people should benefit from conservation projects (Igoe, 2002; Ramutsindela, 2007). However, in reality, conservation and most protected areas remain in the exclusive realm of globetrotting elites who spend tourist dollars to preserve these natural heritage sites. The questions arising here are whose heritage are we protecting and at what cost? These sites of natural heritage continue to be seen as colonial implants that benefit the few rather than locals who bear the costs of living near dangerous wildlife.

Debates about the use of the idea of 'heritage' in the literature on trafficking culture similarly point out the loaded meaning of the term, and for some authors the caprice of local government approaches in 'heritisation' of certain areas of interest (Panella, 2014), which can substantially change in one sweep of the legislative pen the lived experiences of those whose daily routines have interacted with local monuments and sites of historical interest, sometimes going back generations. Again this heritisation discourse is seen as a product of a global museums and collecting field, in which the idea of heritage is really a byword for opening up local issues into global issues and allowing the long arm of colonialism, in the contemporary shape of neoliberal market and conservation interests, to reach in.

The proposition that neocolonial perspectives and a 'west-first' worldview may be part of the backdrop to contemporary issues in development studies is not new. For some time, development has been critiqued as: "necessitat[ing] the diffusion and adaptation of Western values, and help[ing] risk-taking (and Westernized) entrepreneurs produce goods and services for the purposes of economic growth (Rostow, 1960)' (Blaustein, Pino, Fitz-Gibbon, \& White, 2018, p. 4). This is the so-called 'modernisation' approach, in which:

...the strategic concerns of [wealthy countries], rather than [less wealthy countries], were prioritized in development aid schemes, and ... modernization-inspired development programmes served to increase debt and inequality both within and between nation states (Blaustein et al. 2018, p. 5; Cordoso, 1972; Dos Santo, 1970) 
While antiquities looting, wildlife poaching and trafficking can hardly be seen as any kind of official 'development scheme' for source countries, there is a strong sense in the pro-market discourse that there is an overall 'inward investment' type of benefit for source countries to be found in the current global system which extracts ancient artefacts and endangered wildlife from poorer countries and transports them to richer ones. The premises of the modernisation thesis also remain evident in other aspects of the contemporary antiquities discourse, where a considerable part of the justification for collecting in the Global North is seen to be the observed incapacity of 'source' countries in the Global South to protect, preserve and maintain their significant cultural objects to the standards considered appropriate by the connoisseurs of the art market. In curbing antiquities trafficking, expensive and state-of-the art methods such as climate-controlled rooms, theft- and fire-proof display cabinets, security guards and surveillance/ alarm systems are beyond the reach of many source countries. In so failing the particular requirements of preservation standards established in the Global North, these source countries are seen by many art market entrepreneurs as undeserving of the cultural and natural riches scattered throughout the territories they govern. This version of the 'if only they were more like us' critique is of course simply a particular characterisation of that overall theme, which is seen more widely in the 'modernisation' perspective on development as well as in the postcolonial perspective in criminology (Cunneen, 2011).

Similar narratives are pervasive with regards to wildlife conservation in the Global South. Implicit in notions like 'global commons' and 'shared heritage' are neocolonial framings of citizens of the South being too corrupt, too lackadaisical and too capacity-constrained to take care of wildlife. These framings have translated into concrete changes with regards to protected area management. For example, several transnational conservation areas, community-based natural resource management conservancies and some national parks in southern Africa are run or co-managed by private entities or through public-private partnerships. Non-state actors and institutions are thus controlling huge swaths of land put aside for conservation purposes. Local government actors and local communities have been pushed aside as powerful international interests vie for position and control of the 'global commons' (Spierenburg, Steenkamp, \& Wels, 2006; Spierenburg \& Wels, 2010; Zerner, 1999).

A lot more financial support is made available to fight wildlife crime than trafficking culture. Responses to wildlife crime include state-of-the-art technologies like unmanned aerial vehicles (drones) and artificial intelligence. According to a report released by the Global Environmental Facility (2016, p. 9), 24 international donors committed more than US $\$ 1.3$ billion to fight illegal wildlife trade in Africa and Asia between 2010 and June 2016. There have been many more direct and indirect cash injections by private individuals and companies who donate to conservation NGOs and social media interest groups or via online campaigns and crowdfunding initiatives. The lion's share of these financial commitments goes towards law enforcement and antipoaching operations, including the development and implementation of new technologies while training 
and education, awareness raising campaigns and research also receive their fair share.

Funds are used to equip and train rangers and security personnel, as well as the acquisition of new equipment and technologies (Hübschle, 2017b). In some cases, conservation authorities have enrolled the assistance of security and military officials, private investigators and private military and security companies to assist with antipoaching. As is often the case, financial support comes with strings attached, including preferred supplier networks, technical experts and technologies. Critical voices have questioned the efficacy of the antipoaching approach and are asking for accountability in light of the enormous disbursements made to the military-industrial complex (Barichievy, Munro, Clinning, WhittingtonJones, \& Masterson, 2017). A new school of thought critiques militarised responses to poaching, arguing that conservation authorities and their partners are waging a 'war on poaching' with long-term consequences for conservation management and community relations (Duffy et al. 2019).

\section{Collectors Who Want to Collect versus Protectors Who Want to Protect}

In the antiquities and wildlife spheres, we can therefore see two different versions of the modernisation perspective, with each in different ways asking 'developing' countries to open their markets, resources and regulations to opportunities which can more efficiently be exploited by international capitalists.

The antiquities and wildlife markets are founded in colonialism and empire, and this association has received significant scholarly attention (Hübschle, 2016; Yates, Mackenzie, \& Smith, 2017). The deposition of so much of the ancient art and cultural and natural heritages of colonised countries in the major museums of the west is a well-known example of the uneven benefits of colonial arrangements, being a process of cultural, natural and economic enrichment by the dominant powers, very much at the expense of those they were subjugating. As is being increasingly acknowledged, both explicitly through discourse and public apology and implicitly through repatriations and returns of significant objects of ancient art to their countries of origin, the exploitative foundations of many of the great world collections are unsustainable in the moral climate of the present day.

The economic discourse of the last 30 or so years has turned to neoliberal globalisation with its emphasis on the liberalisation of capital markets and an associated push towards deregulation. For the antiquities market, this kind of 'open borders' discourse around trade, development and internationalisation is simply more grist to the Merryman-type cultural internationalism mentioned. Lightly-, going on un-, regulated global free trade is precisely the preferred context for the international market in illicit cultural heritage, since it legitimises the illicit economic practices inherent in illegal trade both in terms of practicality and philosophy. In a world captivated by the purported benefits of global flows of goods and capital, barriers to free trade are anathema. For us to resist this dogma, a frame of reference is needed that allows the debate to step out of a strictly economic viewpoint: this alternative frame needs to respect ideas including 
human rights, global justice and cultural or communal ownership and interest in heritage (Mackenzie \& Yates, 2017).

The debates in wildlife conservation are slightly different. There is an increasing sense that trade regulation and prohibition are leading to untenable high prices of wildlife contraband (Lemieux \& Clarke, 2009) and the increasing viability of illegal wildlife markets in the short-term until the sought-after wildlife goes extinct. The CITES system of regulation has been critiqued as a regulatory tool that reflects the preferences of powerful elite factions in the northern hemisphere that do not have to live with or in close vicinity of dangerous wildlife. A north-south divide and the perceived politicisation of CITES became increasingly evident when the African elephant was moved from Appendix II to Appendix I and the trade ban of ivory products entered into force in 1989. In the run-up to the ban, Western conservation NGOs had campaigned in favour of prohibition. The CITES proposal was adopted despite objections from nine southern African elephant range states, and Japan and China. Back then the elephant populations were considered stable or rising in most of southern Africa. Matters climaxed when a group of southern African countries threatened to withdraw from CITES at the eighth Conference of Parties held in Kyoto. The southern African faction felt that CITES listings were increasingly used for political purposes, and listing decisions were not based on sound scientific data (Mofson, 2000; interview data). Several southern African countries were considering whether to deposit reservations in response to tougher or unchanged trade restrictions in the aftermath of the CITES CoP 18 held in Geneva in 2019. Such reservations if indeed deposited could suspend restrictions in elephant, rhino and elephant trade.

Back in the late 1990s and early 2000s, the disputed elephant listing triggered a larger debate over which conservation paradigms the CITES regime should employ and the sustainable use paradigm was pitted against the preservation paradigm (Mofson, 2000). The southern African faction advocated the sustainable use of wildlife as a conservation tool. According to this paradigm, conservation agencies, local communities and private farmers should be provided with financial, material and other incentives to protect wildlife. CITES tends to focus on the global level of imperilment of a species when determining its listing. In essence, regardless of its status in individual range states, if a species is deemed as endangered at the global level, then its trade may be banned. Through this approach, CITES treats natural resources within individual countries as part of the global commons (Castley \& Hall-Martin, 2003). The listing process has been subject to scathing criticism by countries affected by such decisions. Western experts, scientists and lobbyists are seen as the main catalysts behind the listing of threatened species. Broad consultation with communities that are affected by such listings is perceived to be lacking.

The conservation ideology underpinning the CITES regime in its early days excluded the possibility that trade may hold benefits for species, ecosystems or local people (Martin, 2000, p. 29). While illegal trade might be the principal threat to the survival of endangered species, trade regulations may be inappropriate in dealing with threats such as human encroachment, climate change or organised crime. It was assumed that trade regulation constituted the most effective way of 
achieving conservationist goals (Dickson, 2003) but listings do not only affect the wild fauna and flora that CITES seeks to protect - they also affect the people who live in close proximity to wildlife. In 1992, CITES recognised with Resolution 8.3 that the majority of species it sought to protect were located in the Global South. It also acknowledged that the sustainable use of wild fauna and flora, irrespective of being consumptive or nonconsumptive, provided a viable economic option to local and indigenous peoples (CITES, 1992). Moreover, it was accepted that unless conservation programmes took into account the needs of local people, and provided incentives for sustainable use of wild fauna and flora, conversion to alternate forms of land use might occur (Wijnsteker, 2003). To this day, the issue of sustainable use constitutes a highly contentious issue at CITES Conferences of Parties (CoPs). There is a significant lobby within the environmental movement (predominantly located in the Global North with strategic partners and offices located around the globe) that is vehemently opposed to any trade in animal species, particularly when it is premised on the killing of these animals (Dickson, 2003). This lobby continues to hold considerable sway at CITES, directly and indirectly affecting decisions that lead to restrictions on trade in wildlife. Some southern countries object to the strong influence of animal rights and conservation NGOs at CITES. The antiuse stance is seen as an illegitimate imposition of specific moral values on the wider conservation community.

\section{Sustainable Development as Postcolonial Resistance?}

Against the free-market discourse that supports illicit trade in culture and nature, and the protectionist conservation discourse which in some influential versions limits consideration of local interests, thinking about these problems in terms of sustainability can bring new and different reflections. Let us indicate some of these sustainability insights now.

Thinking first in terms of economic sustainability, the pro-market discourse around global resource-extractive trades implies that wealth trickles down the chain of supply such that consumer purchases in rich countries provide an income for the residents of the poorer source countries (Mackenzie, 2005). This dubious wealth-distribution mechanism is sometimes stretched to presumptively include illicitly obtained commodities along with legal international trade (Fitz Gibbon, 2005).

In the case of illicit antiquities, this argument has been addressed by Brodie who has argued that there is little evidence to support it in practice, and that in fact there is little reason even in principle to think that it would work as described (Brodie, 2010). Antiquities looting is a 'one-shot' form of personal enrichment, with any profit going only to the original looter rather than being spread among the community living in the area of the find. For that community there is detriment, rather than benefit, in the looting, since it deprives them of the longer-term economic benefit that might be obtained from the lost objects, in terms of tourism or lending and display rights. Even the looter achieves only relatively small economic benefit from the crime and it has been suggested that the original looter 
can usually expect to obtain less than 1 percent of the final sale price of the artefact once it has made its way into the international market and been bought by a museum or collector (Brodie, 1998). The biggest cut goes to the intermediaries - the international traffickers - who are hardly a group contributing to sustainable development nor on the list of those in need of benefitting from the UN goals.

With regards to wildlife poaching, recent research on illicit flows of rhino horn (Hübschle, 2016, 2017a; Hübschle \& Shearing, 2018) shows that rhino poachers claim to be fulfilling important societal functions such as social welfare, community development and political leadership. Akin to latter-day Robin Hoods, they see rhino horn as instrumental in achieving these altruistic goals in an environment where the state is largely absent or failing to deliver public services. However, the trickle-down of rhino profits to the broader community is debatable. Many impoverished communities living on the edge of protected areas appear to benefit to some degree, others less so or indirectly (Hübschle, 2017c). Direct handouts include village parties, meat and traditional beer provisions and financial help with school fees. In some instances, wildlife criminals have constructed small roads, boreholes, convenience shops and bars (Hübschle 2017c). Compared to the meagre livelihoods of most rural communities, wildlife criminals have purchasing power, allowing them to buy greater volumes of goods and services, which indirectly benefits community members. These modest local benefits are, however, tempered by an awareness that there is a ceiling to rhino horn fortunes: poachers acknowledged the existential threat to rhinos through poaching and that they would have to seek new sources of income or return to their old ones once the rhinos were gone (Hübschle \& Shearing, 2018). The influx of hard cash into some communities has also had negative consequences, including increased alcohol consumption, illicit drug use and prostitution (Hübschle \& Shearing, 2018, pp. 17-18). As with antiquities trafficking, the biggest cut of the poaching profits goes to the international traffickers and traders. Research interviews by the second author with poachers, traffickers and law enforcers have documented that rhino poachers are paid $6 \%-10 \%$ of the final price that rhino horn trades for in illegal markets. Similar examples of this uneven realisation of the benefits from wildlife contraband are observable in other wildlife economies, such as elephant ivory, abalone and orchids.

Second, we can consider the issue of social sustainability. Crimes against culture and nature fracture and fragment communities. The wildlife crime literature has for some time included discussion of the rights of local populations to sustainably 'use' their wildlife and local ecosystems, as we have mentioned. The incursion of Western norms that speak almost exclusively in terms of protection and preservation make little room for these sorts of sustainable use cases, and the clash of values between locals and their representatives on one hand, and international wildlife protection groups on the other, has become a heated dispute invoking accusations of neocolonialism, paternalism and self-interest (Hübschle \& Shearing, 2020; Mabele, 2017; Neumann, 1998). Likewise, in the debate about 'who owns' cultural heritage (i.e., local populations, or the world), social cohesion is threatened (Cuno, 2008; De Montebello, 2007; Fitz Gibbon, 2005). The looting 
of cultural artefacts and the world trade that drives this leaves cultural groups who identify with artefacts to deal with the aftermath of the losses they experience through these thefts. Studies have found that emotions can run deep in relation to the communal experience of victimhood by way of cultural theft, and in her case studies of policing cultural heritage crime in Latin America, Yates has recorded community reactions as extreme as lynching suspects (Yates, 2014a). This seems to be most likely to occur where the police have become perceived as a distant and uninterested institution of guardianship, and communities fall back into taking the law into their own hands (Yates, 2014a).

Finally, third, we can consider sustainability as a question of justice. Both source and market states, and their constituent actors, have claims to make based on fairness in relation to the prospective movement of culture and nature around the world. The exploitative potential of such global market forces in relation to the illicit extraction of resource from source countries has already been made clear (Efrat, 2012; Naylor, 2011), and a social justice approach to sustainable development would charge us with reducing and preventing those adverse effects as much as possible. On the other side, the pro-market lobby asks why should those who love to appreciate, preserve, collect or use the artefacts of culture or nature be unduly restricted in their capacity to do this by the fact that these items are sequestered away inside the jurisdictional boundaries of other countries that decline to share them in a way the market would appreciate?

This type of thinking prompts consideration of whether broader and higher principles, like those set out in the SDGs, can help to resolve questions of justice when the direction would otherwise be muddied, if not unclear, were we to engage in conciliatory attempts to mediate a resolution to global arguments based on selfinterest alone. The SDGs represent the condensed version of a much wider conversation between nation states about matters of justice and fairness in sustainable development, and as such can make a legitimate claim to be a touchstone for mutually accepted social justice sensibilities as negotiated by the world community, as much as it is represented in the UN.

The relations between global justice and local deprivation, and between international human rights and local understandings of normative conduct, are quite obviously complex - but the constellation of ideas involved in the concept of sustainable development speaks well to the possibilities of a less fractured future relationship between local and global populations and the world's most precious cultural and natural heritage sites.

\section{References}

Barichievy, C., Munro, L., Clinning, G., Whittington-Jones, B., \& Masterson, G. (2017). Do armed field-rangers deter rhino poachers? An empirical analysis. Biological Conservation, 209, 554-560.

Blaustein, J., Pino, N. W., Fitz-Gibbon, K., \& White, R. (2018). Criminology and the UN sustainable development goals: The need for support and critique. British Journal of Criminology, 58(4), 767-786. 
Broad, S., Mulliken, T., \& Roe, D. (2003). The nature and extent of legal and illegal trade in wildlife. In S. Oldfield (Ed.), The Trade in Wildlife: Regulation for Conservation, (pp. 3-22). London: Earthscan

Brockington, D. (2002). Fortress conservation: The preservation of the mkomazi game reserve, Tanzania. Bloomingtion, IN: Indiana University Press.

Brodie, N. (1998, Autumn). Pity the poor middlemen. Culture Without Context, 3, 7-9.

Brodie, N. (2010). Archaeological looting and economic justice. In P. M. Messenger, \& G. S. Smith (Eds.), Cultural heritage management, policy and issues in global perspective (pp. 261-277). Gainsville, FL: University Press of Florida.

Brodie, N., Doole, J., \& Renfrew, C. (Eds.). (2001). Trade in illicit antiquities: The destruction of the world's archaeological heritage. Cambridge: McDonald Institute for Archaeological Research.

Carruthers, J. (1995). The Kruger national park: A social and political history. Pietermaritzburg: Unversity of Natal.

Carruthers, J. (2017). National park science: A century of research in South Africa. Cambridge: Cambridge University Press.

Castley, J. G., \& Hall-Martin, A. J. (2003). The status of the southern white rhinoceros (Ceratotherium simum simum) on private land in South Africa in 2001. Pachyderm, 34, 33-44.

CITES. (1992). Resolution 8.3: Recognition of the benefits of trade in wildlife. Retrieved from https://www.cites.org/sites/default/files/document/E-Res-08-03R13.pdf

Cordoso, F. (1972). Dependency and development in Latin America. New Left Review, 74, July/August, pp. 83-95.

Cunneen, C. (2011). Postcolonial perspectives for criminology. In M. Bosworth, \& C. Hoyle (Eds). What is Criminology? Oxford: Oxford University Press.

Cuno, J. (2008). Who owns antiquity? Museums and the battle over our ancient heritage. Princeton, NJ: Princeton University Press.

De Montebello, P. (2007). Whose culture is it? Museums and the collection of antiquities. Berlin Journal, 15, 33-37.

Dickson, B. (2003). What is the goal of regulating wildlife trade? Is regulation a good way to achieve this goal? In S. Oldfield (Ed.), Trade in wildlife: Regulation for conservation (pp. 23-32). London: Earthscan Publications Ltd.

Dos Santo, T. (1970). The structure of dependence. The American Economic Review, 60, 231-236.

Duffy, R., Massé, F., Smidt, E., Marijnen, E., Büscher, B., Verweijen, J., ... Lunstrum, E. (2019). Why we must question the militarisation of conservation. Biological Conservation, 232, 66-73.

Efrat, A. (2012). Governing guns, preventing plunder: International cooperation against illicit trade. New York, NY: Oxford University Press.

Fioramonti, L. (2014). How numbers rule the world: The use and abuse of statistics in global politics. London: Zen Books.

Fitz Gibbon, K. (Ed.). (2005). Who owns the past? Cultural policy, cultural property, and the law. New Brunswick, NJ: Rutgers University Press.

Floyd, J. P. (1998). Legal and illegal trade between Mexico and the US in plants and plant products listed under CITES. In G. J. Gottfried, C. B. Edminster, \& C. Madelyn Dillon (Comps.), Cross border waters: Fragile treasures for the 21st 
century (pp. 129-138). Fort Collins, CO: U.S. Department of Agriculture, Forest Service, Rocky Mountain Research Station.

Garland, E. (2008). The elephant in the room: Confronting the colonial character of wildlife conservation in Africa. African Studies Review, 51(3), 51-74.

de Greef, K., \& Raemakers, S. (2014). South Africa's abalone trade: An updated overview and knowledge gap analysis. Cambridge: TRAFFIC International.

Harken, J. (2011). Transnational crime in the developing world. Washington, DC: Global Financial Integrity.

Hübschle, A. (2016), A game of horns: Transnational flows of rhino horn. Cologne: International Max Planck Research School on the Social and Political Constitution of the Economy.

Hübschle, A. (2017a). Fluid interfaces between flows of rhino horn. Global Crime, $18(3), 198-217$.

Hübschle, A. (2017b). On the record: Interview with major general Johan Jooste (retired), South African National Parks, head of special projects. South African Crime Quarterly, 60, 61-68.

Hübschle, A. M. (2017c). The social economy of rhino poaching: Of economic freedom fighters, professional hunters and marginalized local people. Current Sociology, 65(3), 427-447.

Hübschle, A., \& de Greef, K. (2016). An exploration of the socio-economic impacts of two drug markets in South Africa. Washington, DC: United States Agency for International Aid.

Hübschle, A., \& Shearing, C. (2018). Ending wildlife trafficking: Local communities as change agents. Geneva: Global Initiative against Transnational Organised Crime.

Hübschle, A., \& Shearing, C. (2020). Conservation, the illegal wildlife trade and local communities. London: Routledge.

Igoe, J. (2002). Fortress Conservation: The Preservation of the Mkomazi Game Reserve, Tanzania by Dan Brockington. International Journal of African Historical Studies, 35(2/3), 594-596.

Lambrechts, D., \& Goga, K. (2016). Money and marginalisation: The lost war against abalone poaching in South Africa. Politik, 43(2), 231-249.

Lemieux, A. M., \& Clarke, R. V. (2009). The international ban on ivory sales and its effects on elephant poaching in Africa. British Journal of Criminology, 49(4), 451-471.

Lynch, M. J., \& Stretesky, P. B. (2014). Exploring green criminology: Toward a green criminological revolution. Farnham: Ashgate.

Mabele, M. B. (2017). Beyond forceful measures: Tanzania's 'war on poaching' needs diversified strategies more than militarised tactics. Review of African Political Economy, 44(153) 487-498.

Mackenzie, S. (2005). Going, going, gone: Regulating the market in illicit antiquities. Leicester: Institute of Art and Law.

Mackenzie, S. (2013). Conditions for guilt-free consumption in a transnational criminal market. European Journal on Criminal Policy and Research, 20(4), $503-515$.

Mackenzie, S., Brodie, N., Yates, D., \& Tsirogiannis, C. (2019). Trafficking culture: New directions in researching the global market in illicit antiquities. London: Routledge. 
Mackenzie, S., \& Yates, D. (2017). Trafficking cultural objects and human rights. In L. Weber, E. Fishwick, \& M. Marmo (Eds.), The routledge international handbook of criminology and human rights. New York, NY: Routledge.

Maguire, T., \& Haenlein, C. (2015). An illusion of complicity: Terrorism and the illegal ivory trade in East Africa. London: Royal United Services Institute.

Margulies, J. D., Bullough, L.-A., Hinsley, A., Ingram, D. J., Cowell, C., Goettsch, B., ... Phelps, J. (2019a). Illegal wildlife trade and the persistence of "plant blindness". Plants, People, Planet, 1(3), 173-182.

Margulies, J. D., Wong, R. W. Y., \& Duffy, R. (2019b). The imaginary 'Asian Super Consumer': A critique of demand reduction campaigns for the illegal wildlife trade. Geoforum, 107, 216-219.

Martin, R. B. (2000). When CITES works and when it does not. In J. Hutton, \& B. Dickson (Eds.),Endangered species. Threatened convention, (pp. 29-37). London: Earthscan Publications Ltd.

Merryman, J. H. (1988). The retention of cultural property. University of California Davis Law Review, 21, 477.

Merryman, J. H. (2005). Cultural property internationalism. International Journal of Cultural Property, 12, 11-39.

Mofson, P. (2000). Zimbabwe and CITES: Influencing the international regime. In J. Hutton, \& B. Dickson (Eds.), Endangered species threatened convention: The past, present and future of CITES, the convention on international trade in endangered species of wild fauna and flora (pp. 107-122). London: Earthscan Publications Ltd.

Naylor, R. T. (2011). Crass struggle: Glitz, greed and gluttony in a Wanna-have world. Montreal, QC: McGill-Queen's University Press.

Neumann, R. P. (1998). Imposing Wilderness: Struggles over livelihood and nature preservation in Africa. Berkley, CA: University of California Press.

Panella, C. (2014). Looters or heroes? Production of illegality and memories of looting in Mali. European Journal on Criminal Policy and Research, 20(4), 487-502.

Rademeyer, J. (2016). Tipping point: Transnational organized crime and the 'war' on poaching (pp. 1-64). Geneva: Global Initiative against Transnational Organized Crime.

Ramutsindela, M. (2006). Parks and people in postcolonial societies: Experiences in southern Africa. New York, NY: Kluwer Academic Publishers.

Ramutsindela, M. (2007). Transfrontier conservation in Africa: At the confluence of capital, politics and nature. Cambridge: CABI.

Reuter, P., \& O'Regan, D. (2016). Smuggling wildlife in the Americas: Scale, methods, and links to other organised crimes. Global Crime, 18(2), 77-99.

Rostow, W. (1960). The stages of economic growth: A non-communist manifesto. Cambridge: Cambridge University Press.

Ruggiero, V., \& South, N. (2010). Green criminology and dirty collar crime. Critical Criminology, 18(4), 251-262.

Shelley, L. I. (2018). Corruption \& illicit trade. Dadalus, 147(3), 127-143.

Spierenburg, M., Steenkamp, C., \& Wels, H. (2006). Enclosing the local for the global commons: Community land rights in the great Limpopo transfrontier conservation area. Conservation and Society, 6(1), 87-97.

Spierenburg, M., \& Wels, H. (2010). Conservative Philanthropists, royalty and business elites in nature conservation in southern Africa. Antipode, 42(3), 647-670. 
Stiles, D. (2015). Elephant ivory trafficking in California, USA. Diani Beach: Natural Resources Defense Council.

The Global Environmental Facility. (2016). Analysis of international funding to tackle illegal wildlife trade. Washington, DC: The World Bank Publisher.

Titeca, K., \& Edmond, P. (2019). Outside the frame: Looking beyond the myth of Garamba's LRA ivory-terrorism nexus. Conservation and Society, 17(3), 258-269.

van Uhm, D. P. (2016). The illegal wildlife trade inside the world of poachers, smugglers and traders. Cham: Springer International Publishing.

UNESCO. (1970). Convention on the means of prohibiting and preventing the illicit import, export and transfer of ownership of cultural property. Paris: UNESCO.

UNODC. (2016). World wildlife crime report: Trafficking in protected species. Vienna: UNODC.

White, R. (Ed.). (2010). Global environmental harm: Criminological perspectives. Cullompton: Willan.

White, R. (2011). Transnational environmental crime: Toward an eco-global criminology. London: Routledge.

White, R. (2014). Environmental insecurity and fortress mentality. International Affairs, 90(4), 835-851.

White, R., \& Heckenberg, D. (2014). Green criminology: An introduction to the study of environmental harm. New York, NY: Routledge.

Wijnsteker, W. (2003). The evolution of CITES: A reference to the convention on international trade in endangered species of wild flora and fauna. Geneva: CITES Secretariat.

Wong, R. W. Y. (2015). The organization of the illegal tiger parts trade in China. British Journal of Criminology, 56(5), 995-1013.

Wyatt, T. (2009). Exploring the organization of Russia far East's illegal wildlife trade: Two case studies of the illegal fur and illegal falcon trades. Global Crime, $10(1 \& 2)$, $144-154$.

Wyatt, T. (2013). Wildlife trafficking: A deconstruction of the crime, the victims and the offenders. London: Palgrave Macmillan.

Yates, D. (2014a). Church theft, insecurity and community justice: The reality of source-end regulation of the market for illicit Bolivian cultural objects. European Journal of Crime Policy and Research, 20, 445-457.

Yates, D. (2014b). Displacement, deforestation and drugs: Antiquities trafficking and the narcotics support economies of Guatemala. In J. Kila, \& M. Balcells (Eds.), Cultural property crimes. Leiden: Brill.

Yates, D., Mackenzie, S., \& Smith, E. (2017). The cultural capitalists: Notes on the ongoing reconfiguration of trafficking culture in Asia, Crime, Media, Culture, 13(2), 245-254.

Zabyelina, Y. G. (2014). The "fishy" business: A qualitative analysis of the illicit market in black caviar. Trends in Organized Crime, 17, 181-198.

Zerner, C. (1999). People, plants and justice: The politics of nature conservation. New York, NY: Columbia University Press. 